\title{
SOVIET COUNTER-INSURGENCY
}

\author{
by S Lt T.D. Potgieter*
}

\section{Introduction}

During the fifties and the sixties of this century counter insurgency was largely in Western hands. The eighties, however, seem to be the age of Soviet counter insurgency. After the Second World War several Western countries conducted counter insurgency campaigns in countries like Indo-China, Greece, Malaya, etc. Contemporary insurgency, on the other hand, seems to be aimed at communist governments in countries that have recently gained their independence. If one regards the fifties and sixties as a period of rising expectations in the Third World, the eighties could be called the age of unfulfilled expectations, because most modern insurgencies take place in countries that have recently become Marxist. ${ }^{1}$

Counter-insurgency is the action taken by (on behalf of) a constituted government against a group or groups waging a revolutionary war or conducting a localized armed rebellion (insurgency) against it, and is aimed at destroying such groups. Thus, counter-insurgency is of a counter-revolutionary nature.

The value Western observers attach to counterrevolution is therefore quiet different from the Marxist connotation. According to the Soviet view counter-revolution is the opposite of revolution. Since the Soviets interpret counter-insurgency as a form of counter-revolution they would never submit to their operations (eg their current war in Afghanistan) being counter-insurgencies. They see their action as protection of the evolution and not as counter-revolutionary. As these kinds of operations are clearly of a counter-insurgency nature, the concept that will be used in this discussion is Soviet counter-insurgency.

Not until this decade did Soviet counter-insurgency gain prominence. Conducting these types of operations are nothing new to the Soviet Union and the utilization of such techniques date from the time of the Czars. The old Imperial Russia would not have succeeded in expanding without the use of power and force. For more than six centuries the state actively oppressed revolt in newly gained territories. One of the oldest principles was to divide their adversaries and encourage the "barbarians to fight barbarians." A second principle was to use mass deportations and to deprive the guerrilla of local support. It was also regarded as essential to place your man in the other fellow's tent; to cultivate and indoctrinate tribal or regionally prominent families and a last hallmark was to gain firm control of cities and towns first. ${ }^{2}$

Since it came into being the Soviet Union has never hesitated to use power in forcing their will upon others. In the 1920's the Red Army crushed the Basmachi rebellion in central Asia with force. During this campaign and other campaigns against insurgents in the Ukraine and Lithuania in particular opposition was eventually crushed by the combined utilization of amour, aircraft and infantry troops by the thousands. ${ }^{3}$

The recent Soviet venture in Afghanistan has shown that the Soviet Union has not deviated from this historical approach. According to reports the campaign is being conducted with alarming ferocity. The Societs use bombs, napalm and artillery fire to destroy the livestock, grain and buildings of villagers suspected of supporting the rebels, villages are sacked, selective psychological operations are conducted against the people of Afghanistan and atrocities are commonplace. While the world expressed a common outrage, observers of the Soviet Union claim that the Soviet methods are consistent with Soviet history. ${ }^{4}$

While the Soviets have the military ability to suppress the insurgency in Afghanistan, their ability to control the insurgents is being questioned. This situation provides a unique opportunity to study Soviet methods in Afghanistan and to determine the exact character of Soviet counterinsurgency. Therefore the goal of this study is to identify important attributes of Soviet counter-insurgency through analysis.

First, the concept of counter-revolution, as it is understood in the Marxist literature, will be discussed. Then attention will be given to the Basmachi rebellion during which the USSR gained valuable experience in counter-insurgency in mountainous terrain. The current campaign in 
Afghanistan is a contemporary example of Soviet counter-insurgency methods. Thus it will be analyzed and generalizations on the nature of Soviet counter insurgency will be made.

\section{Counter-revolution in the Marxist thought}

According to the Great Soviet Encyclopaedia counter-revolution is "a regressive social process that is the direct opposite of revolution. It represents the reaction of the overthrown class (or, the class to be overthrown) to the social revolution and aims at the restoration or preservation of an obsolete social and political order. ${ }^{n}$ Counter-revolution can be seen as the negation of revolution and as such it is mostly interpreted as a reaction to a specific revolution or the process through which the revolution is not just stopped, but is reversed and turned back upon itself $^{6}$

Counter-revolution is thus dependent upon revolution and it is impossible to conceive of counter-revolution without first having a concept of revolution. In accordance with the dialectic materialism revolution constitutes the thesis whilst counter-revolution represents the antithesis. In this clash counter-revolution is "considered to be the reactionary and retrogressive step, bound to lose to the progressive forces of revolution." 7

In accordance with the Communist outlook in the promotion of their cause, counter-revolution will not hesitate to use any means, including subversion, deceit, slander, civil war, conspiracies, terror, demagogy etc. The struggle against counter-revolution could only be successful if it is stopped prematurely and isolated from the masses: "Prompt action must be taken to liquidate counter-revolutionary hotbeds, put a stop to leftist gambles and most important, implement radical revolutionary reforms in the interest of the working people and tackle creative revolutionary tasks. The history of the revolutionary movement proves that victory over counter-revolution may only be achieved by way of developing the revolution, bringing it to its consummation. ${ }^{9}$

Counter-revolutionary forces usually count on international support and the communists see imperialism as the bulwark of counter-revolution. The socialist states of the world are waging a "determined struggle against the imperialist export of counterrevolution and are offering many types of support to the peoples who have become the victims of armed aggression." ${ }^{10}$ Armed intervention is thus conscionable which gives the Armed Forces of the Soviet Union an external function. It is regarded as their duty to serve as an obstacle to interference by "world imperialism" in the affairs or nations engaged in "wars of national liberation."

According to a prominent Soviet military author, Konstantin A. Voro'yev the task of the external function is to suppress the export of counterrevolution in every possible way. "This activity of socialist armies, primarily of our Armed Forces, in present-day circumstances with full justification might be classified as one of the most important sides of their external function, directed at suppression of the export of imperialist counter-revolution ..." ${ }^{11}$ While world imperialism strives to end the "inevitable process of world revolution" and to stop the "liberation of the peoples of the world", the USSR and other communist countries see it as their duty to help the people struggling for their "freedom and liberation" in every possible way.

The concept counter-insurgency is basically never used in the Marxist and communist literature because they associate it with "rightist regimes." These kinds of regimes are usually being supported by the West and in accordance with this perception counter-insurgency are defensive or annihilating campaigns against revolutionary forces. Communism denounces counter-insurgency as a form of counter-revolution, a pretext for the "imperialist" powers to interfere in the local affairs of countries and an excuse for conducting hostilities against "national liberation movements."

The Communists regard it as their duty to do their best to destroy counter-revolution with every means necessary. ${ }^{12}$ Although the USSR conducts a campaign that could be called a counter insurgency campaign against the Mujahideen, their presence in Afghanistan is of the utmost importance for the progressive consummation of the revolution and it is deemed a historical necessity to nullify counter-revolution.

\section{The Basmachi Rebellion}

The Basmachi rebellion that took place during the 1920's in the southern Soviet Socialistic Republic of Tadzhic was an armed struggle initiated by Moslem leaders. Their aim was an independent government. According to the Great Soviet Encyclopaedia the Basmachi was 
an "armed counter revolutionary nationalist movement" that was supported by the USA and Britain and also received aid from Turkey, Afghanistan and China. The rebellion is also looked upon as part of the class struggle as "... bands of Basmachi initiated armed struggle against the Soviet government with the intention of separating Turkestan from Soviet Russia and establishing a government of the nationalist bourgeoisie and feudal lords under the protection of foreign governments." ${ }^{13}$

Initially the Basmachi conducted raids and surprise attacks against Soviet military units, industrial strongholds, railroad stations, depots, etc. In 1919 the movement decided to conduct a unified military and political campaign against the government of the USSR. The new strategy was successful and resulted in the Basmachi capturing parts of East Bukhara.

This resulted in the Basmachi being a serious threat to the government of the Soviet Union, whereupon the Bolshevist Central Committee adopted decisive measures for the liquidation of the Basmachi and decided to combine their military actions with political efforts and economic measures. As part of the new measures detachments of the volunteer militia and the nationalist units of the Red Army rendered much assistance to the regular units of the Red Army in the struggle with the Basmachi. In this way the struggle was localized to a greater extent, the enemy were divided and the Red Army could gain more success with local help. It was not until 1926, however, after considerable suffering by the economy and the people of that area the rebellion was finally suppressed. ${ }^{14}$

In their efforts to neutralize the rebellion the Soviets combined military-political and economic factors with Leninist policy. According to the Great Soviet Encyclopaedia "the implementation in Middle Asia of Leninist principles of national policy and Party measures for the development of the ... economy (favorable taxation, commercial development, water and land reform and so on) played a large role in the liquidation of the Basmachi."15

After the First World War the USSR quickly recognized the value the new weapon, the aircraft, had for unconventional warfare. Therefore, during the Basmachi rebellion they utilized airpower with success in the elimination of opposition. In an article, A.N. Lapchinsky, a Russian and an early champion for airpower explained how enemy groups were attacked by aircraft and how airborne landings were used "in the desert during the struggle with the Basmachi."16 During the 1980's Soviet airborne units became a formidable weapon for the projection of Soviet military power. In Afghanistan armed forces rely heavily on airpower and in the mountainous terrain they immediately recognized the indispensable value of aircraft and helicopters.

Despite the fact that it took the Soviet Union nearly a decade (1917-1926) to put down the rebellion, they gained valuable and relevant experience in counter-insurgency and unconventional warfare in mountainous terrain. ${ }^{17}$ These lessons are of great importance for the campaign in Afghanistan. It took the Soviet Union quite some time to re-learn them.

\section{Afghanistan}

The world reacted in shock to the USSR's invasion of Afghanistan in December 1979, especially since it happened after a decade of detente between the Superpowers. Many states, for example Red China and Pakistan immediately gave their active support to the Afghan resistance - the Mujahiddeen. If it is taken into consideration that the USSR has the fifth biggest Moslem population in the world the reasons for Moscow's interference in Afghanistan becomes clearer. ${ }^{18}$ The USSR feared that the successful Moslem revolution in Iran and the unrest in Afghanistan might trigger off a revolt under the 50 million Moslems in one of its southern republics (Turkmenistan, Oesbekistan, Tadjikistan). Thus it decided to meddle in the affairs of Afghanistan.

During the nineteenth and twentieth centuries Britain and Czarist Russia tried to have Afghanistan under their influence. Their efforts were in vain and after the First World War in 1921 the Kingdom of Afghanistan was recognized as a independent state. ${ }^{19}$

In the fifties and sixties efforts were conducted at modernizing the kingdom and the economy and a constitutional monarchy was established in 1964. It was not successful because the King in effect vetoed certain important political processes that were guaranteed in the constitution. This resulted in a Coup and the fall of the monarchy in 1973. The new Republic of Afghanistan with Daud Khan as the Premier came into being. ${ }^{20}$ 
Daud Khan tried to implement a new constitution, stimulate socio-economic development and to move away from the initial socialist inclination of the new republic. The country however was unstable and reform resulted in unrest, revolt, political murders and a coup. Out of this turmoil, the Democratic Republic of Afghanistan came into being on 27 April 1978. ${ }^{21}$ Mohammed Takari became the new President of the Revolutionary Council, Premier and Secretary-general of the Democratic Peoples Party of Afghanistan.

Known for their use of Marxist-Leninist rhetoric, the Takari regime's policy and reforms, were not successful. After unrest and several shuffles in the government Hazifullah Amin became the new Premier in March 1979. Takari remained President of the Revolutionary Council. The violence and unrest continued and Amin asked the USSR for greater assistance in the form of military advisers, weapons and provision.

During September Takari was killed in a clash between his supporters and supporters of Amin. Amin then took the power in his hands. He tried in vain to enlarge his support, but the Takari supporters continued their opposition towards the government. The situation in Afghanistan deteriorated and during the last week of December 1979 the USSR invaded Afghanistan. Amin and some of his followers died in the ensuing violence. ${ }^{22}$

Babrak Karmal became the new Premier and President of the Revolutionary Council. Opposition against the Karmal government and the USSR's presence in Afghanistan gained momentum. Unrest in the cities and violence spread through the country and escalated during 1980. Many Afghan refugees soon took to their neighbouring states, like Pakistan. ${ }^{23}$ The presence of the USSR became a necessity in Afghanistan. Without it the Afghan government would not be able to remain in power.

The events in Afghanistan immediately before the Soviet invasion were essential for the USSR'S decision to invade. Their initial motives could have been restricted to the aim to replace Amin with Karmal while they believed that the Red Army would be able to contain the insurgence. Their presence, however, inflamed the situation. ${ }^{24}$ The interference with the local politics in Afghanistan became a long term commitment and it was soon realized that no short term solution was possible.
In the effort to establish themselves in Afghanistan the Soviets used a three-pronged strategy: First there is a military campaign to eliminate all opposition; the second facet concentrates on securing strategic-military control of the country by holding cities, towns and the main lines of communication and in an effort to crush the resistance they depopulate the countryside; and lastly the Afghan government is being remodelled along the Soviet lines in an effort to establish communism as effectively as possible. ${ }^{25}$

\section{The resistance}

Within the first few weeks after the Soviet invasion the resistance - the Mujihaddeen - began a guerrilla campaign against the Soviet forces. Members of the resistance swore that they would not stop the fighting until the USSR had left Afghanistan. The USSR answered with violence and utilized their modern and deadly weapons in the struggle against the Mujihaddeen. ${ }^{26}$ Despite the USSR's advantage with regards to weaponry and firepower the resistance does not show any signs of capitulation. Their courage had led to great successes, while they have the ability to draw out the war and even fight it in the centre of the enemy's power.

In the long term the prospects do not look very rosy for the resistance. They have a serious shortage of manpower - about one third of the population of Afghanistan are refugees and the resistance has had between 50000 and 100000 casualties $^{27}$ In addition their ability to fight is being tried by the economic war. They need more and modern weapons for the continuation of the struggle and must receive better training in weaponry and guerrilla tactics. ${ }^{28}$ Little unity between the different factions of the resistance also results in the absence of clear strategic goals and a co-ordinated effort.

The effects of the war have reached all facets of the Afghan society and economy and have changed the traditional set-up remarkably. In the breaking of the old, the war established a new pattern. A revolution has therefore taken place in Afghanistan.

\section{Soviet Counter-measures in Afghanistan}

According to the USSR its presence in Afghanistan was caused by the exploitation of the people of Afghanistan by the imperialist powers. Its presence is essential for the protection of the 
people of Afghanistan, to protect the revolution and to see to it being carried to its consumation. ${ }^{29}$ According to the Soviet media the USA tried during the forties to extend their influence in Afghanistan because of its strategic value. After the coup of 1973 Kissinger also tried to extend American involvement in Afghanistan. At the same time the oppression of the "progressive classes" (the powers of Communism and revolution) increased. The USA did their best to destroy the revolution in Afghanistan, gave weapons to the counter revolutionaries and supported "terror and subversion." After the "national democratic revolution" of April 1978 the USA began a undeclared war against the people of Afghanistan. According to the Soviet Military Review by their doings the USA illustrates to the people of the world that it is a supporter of the "policy and practice of state sponsored terrorism" ${ }^{30}$. Since revolution and counter revolution are dialectically linked together, it is the duty of the Communist world and specifically the USSR to destroy what it sees as counter revolution.

Despite the ideological, rhetoric and idealistic phrases the Soviet Forces are in effect fighting a counter insurgency in Afghanistan. Initially they underrated their opponent and tried to dissolve a political-social problem in a military way. No doctrine for this kind of war has as yet arisen from the Soviet experience in Afghanistan. In the suppression of revolts the Soviet Union are known to be inaccessible and their methods are the product of historic experience. ${ }^{31}$

As the Soviet Union rely heavily on military power their strategic and tactic principles are frequently not recognized. Thus a few important attributes of Soviet counter-insurgency will be discussed in short.

\section{Military-technology}

The USSR campaign in Afghanistan is characterized by their deployment of a large amount of troops, modern weaponry and equipment. They try to overwhelm the guerrillas with sheer numbers and with force. At this stage there are approximately 120000 Soviet troops, included the highly trained "Spetsnaz" units, in Afghanistan. At least 400000 of the Soviet Union's two million troops have already seen service in Afghanistan, while they have suffered about 20000 casualties. This resulted in poor morale within the ranks. ${ }^{32}$ By 1983 the combined Soviet and Afg- han forces had about 1420 light and medium tanks, 1685 artillery pieces, 281 aircraft and 220 helicopters in the field. ${ }^{33}$ Currently the Soviets have approximately 450 fixed wing aircraft and 600 helicopter (of which about 250 are combat helicopters) in Afghanistan. ${ }^{34}$ The Soviet forces rely heavily on aircraft and helicopters in their attacks on the guerilla and prefer to fight in this way rather than face the guerrillas in ground combat.

According to Keegan the Soviets employ their advantage in technology and firepower as follows: "Effectively what the Russians did from 1982 onwards was deem the whole of rural Afghanistan a fire-free zone, with the aim of driving the country people into the cities (a million have been displaced in that direction) or out of the country altogether. But not even the cities were safe. One third of Qandahar was destroyed by artillery bombardment as early as June 1981." ${ }^{135}$ Information from Afghanistan proves that the Soviets have no regard for basic human rights. According to a United Nations report civil casualties for 1985 are calculated at about 35000 . Oppressive measures are applied and some sources estimate that as many as five million Afghans have been made refugees since the Soviet invasion. ${ }^{36}$

\section{Economic warfare}

Economic Warfare and food control (some sources use the term famine) are typical techniques the Soviets apply in the liquidation of resistance. In the 1930's opposition against collectivism in Ukraine was crushed by famine which took six million lives. Destroying the economic base of a area is seen as a effective way through which resistance can be eliminated. ${ }^{37}$

These methods are also applied in Afghanistan. Since the invasion food prices have risen by about $145 \%$ and "... the Soviets welcome economic problems - they force the peasants away from areas known to be centres of guerrilla activity in the fertile valleys and into the cities where they can be more easily controlled. ${ }^{38}$

According to some reports this economic war is the greatest threat to the guerrillas ability to continue with the war. Their tactics include: destroying crops with napalm bombardments; planting anti-personnel mines in fields to prohibit the farmers to work their lands, and in some cases primitive but essential irrigation networks are 
even destroyed. $^{39}$ To cause hunger among the population in the areas where the resistance is strongest by destroying the agriculture, is an old Soviet strategy and has certain short term advantages.

\section{Establishing of authority in cities and towns}

The same pattern by which the imperial forces in the Czarist times established their authority in the cities and towns and afterwards gained a foothold in the countryside, can be seen in Afghanistan today. Efforts are made to depopulate the countryside in order to liquidate the resistance. It is easier to control people that are concentrated in cities and towns than to exercise authority over people that are scattered over a large area. ${ }^{40}$ No serious efforts are undertaken to control the country, but "... the towns are used as garrisons and as logistical stepping stones. They provide storage facilities, aviation bases, barracks and strongholds." 41 Garrisons frequently have their own airfield or airforce base and great effort is employed in always keeping the channels of communication open.

\section{Strict measures against renegades}

Severe measures against spies and deserters are another characteristic of the conflict in Afghanistan. Many Moslem troops in the Red Army and in the Afghan Army sympathize with the resistance and they often desert with their weapons or sell them on the black market or to the resistance. Penalties for guerrilla collaborators and deserters are very severe. According to reports if deserters are caught they are sent back to the Soviet Union and nothing is heard of them again. They are presumed to be executed. $^{42}$

\section{Localizing (Afghanistanizing) of the conflict}

The USSR is prepared to use their own forces to stabilize the situation, but after that they would like to "Afghanistanize" the struggle. After the Soviet invasion in 1979 Amin ('n loyal MarxistLeninist) was removed because he had lost control over the situation and Karmal was put in his place. Since then Karmal too was replaced by the former chief of the Secret Police, Najibullah. Najibullah's expertise in the use of secret police could place Afghanistan firmer in Soviet hands without the Soviets having to do all the dirty work. The USSR is prepared to do anything necessary in Afghanistan, but would prefer to use its own forces as little as possible. ${ }^{43}$

For the reasons mentioned above the KGB is lending a helping hand to KHAD (Afghan Security Police), supports efforts to enlarge and improve the local Police Force, trains members of the Police and Security Police and directs efforts at organising the militia and civil forces and placing them on a substantial foundation. ${ }^{44}$ The Soviets use an increasing amount of Afghan soldiers and endeavour to change the unmotivated and unreliable Afghan Army into a formidable fighting force. That is a difficult task since the centre of Afghan Army consists of unmotivated conscripts, and desertions to, and spying for the resistance are commonplace. Despite the fact that they are a junior partner in joint operations, the USSR sees the Afghan Army as a integral part of the struggle against the guerillas and militia and local units are playing a larger role. Thus, it seems that the creation of a Afghan Army that is loyal to the current regime is becoming a reality. ${ }^{45}$

This aspect is reminiscent of the old imperial principle to encourage "barbarians to fight barbarians." It also compares with the efforts of the Americans to "Vietnamize" the struggle in Vietnam. The USSR prefers to keep regional conflicts localized, but will for economic reasons restrict their involvement in the Third World. This aspect is not placed on ideological grounds. ${ }^{46}$ The involvement of other states and the controversy their invasion has caused, shows the Soviet Union that it is impossible to keep regional conflicts in isolation.

\section{Exploitation of differences in the enemies ranks}

According to the Czarist principle the Russians try to exploit differences in their enemies ranks. One of the main tasks of KHAD (Security Police) is to infiltrate the resistance and exploit the differences between the different factions of the Mujahiddeen. ${ }^{47}$ The lack of co-operation within the Mujahiddeen benefits the Soviets since there is no real co-ordination and unified effort from the resistance.

\section{Intelligence}

Like so many Western countries the USSR realized that a thorough intelligence community is 
an essential element for success in this kind of war. The Afghan Security Police is modelled along the lines of the KGB. It controls intelligence, counter-intelligence, spying etc. and works in close co-operation with the local militia. $\mathrm{KHAD}$ is quite successful against the resistance and with the help of Soviet funds they are able to keep a network of approximately 20000 paid informants, in the country and over the border. ${ }^{48}$ $\mathrm{KGB}$ personnel are working in KHAD posts in Kabul and are also responsible for the training function. Wheeler mentions the following about KHAD: "Although rife with factionalism, it is able, nevertheless to spread terror and suspicion." 49

\section{Political education}

To ensure domination of a people one must begin with the youth. In Afghanistan this is the modus operandi. Education received a high political content. Education and training are coupled with politics and ideology and special youth organizations were created to foster the right attitudes among the children. Children can become Young Pioneers, a organization organized along Soviet lines and under the protection of the Communist Party of Afghanistan. Specialists from the USSR, East Germany and Czechoslovakia were imported for this reason and are doing major work on his terrain. A lot of the lecturers at the universities have fled the country while other were discharged. They were replaced with Soviet citizens and the entire educational system in Afghanistan was reorganized on the basis of the Soviet model. ${ }^{50}$

\section{Control over the media}

Revolutions and counter-insurgencies in modern times proved that control over a country's media is one of the most important variables in the influencing and control of the masses. The Soviets are masters in the manipulation and utilization of this powerful weapon and machine of propaganda. Not only in Afghanistan do they control reports, but also in the mother country do they keep the true facts of the war from the people. The message the people in the Soviet Union receive is that in order to contain capitalism and imperialism it is the duty of the USSR to intervene. ${ }^{51}$ Initially the media reported that the Soviet Forces in Afghanistan are only performing police duties and their task was to protect civilians. Nowadays a different picture is drawn. They acknowledge that Soviet troops are fighting and are even slain, but the media in the
Soviet Union only report on their heroic deeds and compare it with the Soviet soldiers during the Second World War. ${ }^{51}$

\section{Conclusion}

The discussion has shown that although the USSR denies undertaking any counter-insurgency operations it is in effect a fundamental part of their doings. They, however, see their actions as essential for the elimination of counter-revolution. This is not only relevant for combating revolts within the USSR, but also in other countries where communist revolutions took place the objective of the Soviet Union is to destroy the insurgents (counter-revolutionaries according to the Soviet perception) the enemies of the newly found communist country.

Despite several similarities between Western and Soviet counter-insurgency, the differences between the two are noteworthy. The aim of Western counter-insurgency is to prevent a revolution and it normally takes place in a potentially revolutionary situation. In other words during the period before the revolution in order to try and contain the revolution or to counter the revolutionary potential. Modern Soviet counter-insurgency usually takes place after the revolution and it is mostly in an effort to rescue the new communist state from ruin. In the West counterinsurgency is aimed at preserving the status quo, while Soviet counter-insurgency aims at establishing a revolutionary order.

The Soviet Union's long history in the elimination of revolts and the methods used during such campaigns created the pattern on which modern Soviet counter-insurgency is based. The Soviet methods can clearly be seen by analysing the current war in Afghanistan. True to Soviet methodology force and violence are used in an effort to eliminate opposition by military means. One of the first things Soviet Forces usually do, is to establish their power strategically and to control the main centres. An economic campaign against the population comes next. In this sense Afghanistan was in accordance with Soviet methods.

Even though a "hearts and minds" attitude is not the highest priority in Afghanistan much attention is being paid to the establishing of the communist ideology. Since Communism is a totalitarian ideology and the Soviets are masters of indoctrination and the influencing of the masses, a selected psychological campaign is being 
undertaken. The youth is the easiest to influence, therefore it is seen as payable to launch such a campaign amongst the younger generation. For this reason the system of education was reformed and a lot of attention is paid to the indoctrination of the youth. Furthermore the USSR regards the control of public opinion also as important. Therefore the media is under strict control, and any renegades are treated severely.

In accordance with Soviet policy regional conflicts must be kept local. The Soviet Union tries to keep its participation in wars in the Third World as indirect as possible. The process of "Afghanistanization" is in correlation with Soviet policy. The USSR prefers to use its own forces as little as possible.

Ideological and philosophically the Soviet Union justifies its counter-insurgency as a struggle against counter-revolution. Militarily it draws from the methods of the Czars and from their experience in the suppression of several revolts during this century. Although, according to several observers, no coherent Soviet doctrine of counter-insurgency has emerged, they definitely have a unique attitude in the suppression of revolts and rebellion and in this they are definitely not unsure or half-hearted.

* S Lt T.D. Potgieter, BA Hons History and Strategic Studies is attached to the Military Academy

\section{References}

1. R. Paschall: Marxist Counterinsurgencies. Parameters, volume XVI, $n r 2$, p2.

2. Ibid., pp5-6.

3. J.M. Hutcheson: Scorched-Earth Policy: Soviets in Afghanistan. Military Review, vol LXVII, no 41, Apr 1982, p30.

4. Ibid.

5. Great Soviet Encyclopeadia, vol 13, p203.

6. L. Brownstein: The Concept of Counterrevolution in Marxian Theory. Studies in Soviet Thought, nr 22, 1981, pp177-181.

7. J. Wilczynski: A Encyclopedic Dictionary of Marxism, Socialism and Communism, 053 .

8. Great Soviet Encyclopaedia, vol 13, p204.

9. A Dictionary of Scientific Communism, p54.

10. Great Soviet Encyclopaedia, vol 13, p204.

11. H.F. Scott and W.F. Scott: The Soviet Art of War, Doctrine, Strategy and Tactics, p255.

12. L. Brownstein: op cit, p180.

13. Great Soviet Encyclopaedia, volume 3, p57.

14. Ibid. volume 25, p290.

15. Ibid., volume 3 , pp57-58.

16. H.F. and W.F. Scott: The Soviet Art of War, pp64-65.

17. I.F.W. Beckett en J. Pimlott: Armed Forces and Modern Counter-Insurgency, pp9-10.

18. J.F. Kirsten: Die Sowjetunie se stryd in Afghanistan. Oënskou, vol 3, nr 4, May 1984.

19. The New Encyclopaedia Brittanica, pp172-177.

20. A. Hyman: The struggle for Afghanistan. The World Today, July 1984, pp276-277.

21. R.S. Newell: Soviet Intervention in Afghanistan. The World Today, July $1980,0251$.

22. A. Hyman: op cit, p277.

23. R.S. Newell: op cit, $\mathrm{p} 255$.

24. L.G. Wheeler: The Forces in Conflict. Military Review, July 1980, 059.
25. N.M. Kamrany: The Continuing Soviet War in Afghanistan. Current History, October 1986, pp334-335 en A.Z. Rubinstein: Afghanistan at War. Current History, March 1985.

26. A. Hyman: op cit, pp282-283.

27. Ibid.

28. R.S. Newell: op cit, 025 .

29. I. Ilyichov: Soviet-Afghan Cooperation. Societ Military Review, October $1985, \mathrm{pp} 53-54$

30. Y. Zabrodotsky: USA: Policy of State Terrorism. Soviet Military Review, September 1985, p55.

31. R. Paschal: 00 cit, $p D 2-3$.

32. M. Johns: op cit, $p 4$.

33. J.F. Kirsten: Die Sowjetunie se Stryd in Afghanistan. Oënskou, May $1985, \mathrm{p} 180$.

34. C.G. Wheeler: op cit, p55.

35. J. Keegan: op cit, $p 103$.

36. A.Z. Rubinstein: Speculations on a National Tragedy. Orbis, Winter 1987, pp605-606.

37. K. McCormick: The Evolution of Soviet Military Doctrine. Military Review, July 1980, pp69-70.

38. Ibid., p69.

39. J. Keegan: op cit, p103.

40. A. Hyman: op cit, $\mathrm{p} 281-282$.

41. A.Z. Rubinstein: op cit, $p 129$.

42. M. Johns: op cit, p14.

43. Ibid., p4.

44. A. Hyman: op cit, p281

45. A.Z. Rubinstein: op cit, $p 590$.

46. J.F. Kirsten: op cit, $p 180$.

47. C.G. Wheeler: op cit, p56

48. A. Hyman: op cit, $p 281$.

49. C.G. Wheeler: op cit, $p 56$.

50. A. Hyman: op cit, pp278-279

51. R. Oplatka: The Home Front in Moscow's Afghan War. Swiss Review of World Affairs, Augustus 1986, pp25-26.

52. R. Oplatka: op cit, pp20-27 en Y. Besschyotnov: In the skies over Afghanistan. Soviet Military Review, February 1986, pp29-30.

\section{Bibliography}

A Dictionary of Scientific Communism. Progress Publishers, Moscow, 1984. BECKETT, I.F.W. and J. Pimlott: Armed Forces and Modern Counter-Insurgency. London, Croom Helm, 1985

BESSCHYOTNOV, Y.: In the Skies over Afghanistan. Soviet Military Review, no 2, February 1986.

BROWNSTEIN, L.: The Concept of Conterrevolution in Marxian Theory. Studies in Soviet Thought, no 22, 1981.

Great Soviet Encyclopaedia.

HUTCHESON, J.M.: Scorched-Earth Policy: Soviets in Afghanistan. Military Review, April 1982.

HYMAN, A.: The Struggle for Afghanistan. The World Today, vol 40, nr 7 , July 1984.

ILUICHOV, I.: Soviet-Afghan Cooperation. Soviet Military Review, no 10, October 1985.

JOHNS, M.: The Lessons of Afghanistan. ISSUP Bulletin, Institute for Strategic Studies, Pretoria University, 3/87, Junie 1987.

KAMRANY, N.M.: The Continuing Soviet War in Afghanistan. Current History, October 1986.

KEEGAN, J.: The Ordeal of Afghanistan. The Atlantic Monthly, November 1985.

KIRSTEN, J.F.: Die Sowjetunie se Stryd in Afghanistan. Oënskou, vol 3 no 4 , May 1985.

McCORMICK, K.: The Evolution of Soviet Military Doctrine. Military Review, July 1980 .

NEWEL, R.S.: Soviet intervention in Afghanistan. The World Today, vol 36 no 7. July 1980.

OPLATKA, A.: The Home Front in Moscow's Afghan War. Swiss Review of World Aftairs, vol 36, no 5, Augustus 1986.

Paschall, R.: Marxist Counterinsurgencies. Parameters, vol XVI, no 2, Somer 1986.

RUBINSTEIN, A.Z:: Afghanistan at War. Current History, March 1986.

RUBINSTEIN, A.Z: Speculations on a National Tragedy. Orbis, Winter 1987.

SCOTT, H.F. and W.F. SCOTT: The Soviet Art of War. Doctrine Strategy and Tactics. Boulder, Westview Press, 1982.

WHEELER, L.G.: The Forces in Conflict. Military Review, July 1980.

WILCZYNSKI, J.: A Encyclopedic Dictionary of Marxism, Socialism and Communism. Macmillan, London, 1981.

ZABRODOTSKY, Y.: USA: Policy of State Terrorism. Soviet Military Review, no 9 , September 1985. 